\title{
Phosphorylation of calmodulin by the epidermal-growth-factor-receptor tyrosine kinase
}

\author{
Alberto BENGURÍA ${ }^{1}$, Octavio HERNÁNDEZ-PERERA ${ }^{1}$, María Teresa MARTÍNEZ-PASTOR ${ }^{1}$, David B. SACKS ${ }^{2}$ \\ and Antonio VILLALOBO ${ }^{1}$ \\ 1 Instituto de Investigaciones Biomédicas, Consejo Superior de Investigaciones Científicas, Madrid, Spain \\ ${ }^{2}$ Brigham and Women's Hospital and Harvard Medical School, Boston, USA
}

(Received May 31/July 21, 1994) - EJB 94 0779/1

An epidermal-growth-factor(EGF)-receptor preparation isolated by calmodulin-affinity chromatography from rat liver plasma membranes is able to phosphorylate calmodulin. Calmodulin phosphorylation was enhanced 3-8-fold by EGF, was dependent on the presence of a polycation or basic protein and was inhibited by micromolar concentrations of $\mathrm{Ca}^{2+}$. Phosphate incorporation into calmodulin occurs predominantly on tyrosine residues. Partial proteolysis of phosphocalmodulin by thrombin identifies Tyr99, located in the third calcium-binding domain of calmodulin, as the phosphorylated residue. Stoichiometric measurements show a ${ }^{32} \mathrm{P} /$ calmodulin molar ratio of approximately 1 when optimal phosphorylation conditions are used.

Calmodulin is an intracellular calcium receptor that mediates multiple essential functions in eukaryotic cells (Means and Dedman, 1980; Klee et al., 1980; Klee and Vanaman, 1982; Manalan and Klee, 1984; Veigl et al., 1984; Strynadka and James, 1989; Bachs et al., 1992), including the regulation of cell proliferation (Veigl et al., 1984). In this context, it has been demonstrated that this ubiquitous regulator can control multiple nuclear processes (Bachs et al., 1992). Nevertheless, the role of calmodulin in cell proliferation does not appear to be exclusively exerted at the level of the nucleus. Recently we have demonstrated that the epidermal growth factor (EGF) receptor can be isolated by calmodulin-affinity chromatography, and that calmodulin inhibits its tyrosine kinase activity (San José et al., 1992). Calmodulin, therefore, could potentially play a regulatory role in the EGF-mediated mitogenic-signal pathway.

Calmodulin has been shown to be a substrate for several different protein kinases (Plancke and Lazarides, 1983; Häring et al., 1985; Fukami et al., 1985; Graves et al., 1986; Lin et al., 1986; Nakajo et al., 1986, 1988; Meggio et al., 1987, 1992; Kubo and Strott, 1988; Sacks and McDonald, 1988; Laurino et al., 1988; Sacks et al., 1989a, 1992a; San José et al., 1992; Benguría et al., 1993; Saville and Houslay, 1994). Since this phosphorylation process occurs in intact

Correspondence to A. Villalobo, Instituto de Investigaciones Biomédicas, Consejo Superior de Investigaciones Científicas, Arturo Duperier 4, E-28029 Madrid, Spain

Fax: +3415854587 .

Abbreviations. EGF, epidermal growth factor; EGFr, epidermal growth factor receptor; $\mathrm{PhMeSO}_{2} \mathrm{~F}$, phenylmethylsulfonyl fluoride; CaM, calmodulin; P-CaM, phosphocalmodulin; TosPheCH $\mathrm{H}_{2} \mathrm{Cl}$, Ltosylamido-2-phenylchloromethyl ketone; poly-(L-Glu $\left.{ }^{80}, \mathrm{Tyr}^{20}\right)$, copolymer of L-glutamic acid and L-tyrosine in a 4:1 molar ratio.

Enzymes. Protein-tyrosine kinase (2.7.1.112); protein kina . (2.7.1.37); thrombin (3.4.21.5); 3',5'-cyclic-nucleotide phosphodiesterase (3.1.4.17); $\mathrm{Ca}^{2+}$-dependent protease (3.4.22.17); trypsin (3.4.21.4); phospholipase $\mathrm{C}$ (3.1.4.3); phospholipase $\mathrm{A}_{2}$ (3.1.1.4); lipoxygenase (1.13.11.12). cells (Plancke and Lazarides, 1983; Fukami et al., 1985; Nakajo et al., 1986; Colca et al., 1987; Sacks et al., 1992b), phosphocalmodulin could play an important role in the physiology of the cell. In support of this, it has been shown that phosphorylation of calmodulin by casein kinase-2 (an insulin-sensitive and EGF-sensitive serine/threonine kinase) alters the biological activity of calmodulin by decreasing the activation of two calmodulin-dependent enzymes, myosinlight chain kinase and cyclic-nucleotide phosphodiesterase (Sacks et al., 1992a). Additionaly, phosphorylation of calmodulin in Tyr99 by the insulin receptor decreases the action of calmodulin antagonists on the type-I cyclic-nucleotide phosphodiesterase, although it does not affect the calmodulin dependency of this enzyme (Saville and Houslay, 1994).

In a short communication Lin et al. (1986) reported that plasma membrane fractions from the human epidermal carcinoma cell line A431, which overexpress the EGF receptor, can be used to phosphorylate calmodulin in the presence of EGF. However, the authors indicated that this phosphorylation takes place on serine residues (Lin et al., 1986), suggesting that the EGF receptor is not directly involved in the phosphorylation process. We have noticed that calmodulin can be phosphorylated by an EGF-receptor preparation isolated by calmodulin-affinity chromatography (San José et al., 1992). In this study we present a comprehensive characterization of this phosphorylation process.

\section{MATERIALS AND METHODS}

\section{Chemicals}

Radiolabeled $\left[\gamma_{-1}{ }^{32} \mathrm{P}\right] \mathrm{ATP}$ (triethylammonium salt) $(3000-5000 \mathrm{Ci} / \mathrm{mmol})$ was purchased from Amersham, and X-Omat AR X-ray films were purchased from Eastman Kodak. Molecular-mass standards for electrophoresis were obtained from Bio-Rad, and thrombin and bovine brain calmodulin were from Calbiochem. Calmodulin-agarose, phenyl- 
Sepharose, ATP (sodium salt), leupeptin, EGF (from mouse submaxillary glands), phosphotyrosine, phosphoserine, phosphothreonine, histone (type II-AS), Triton X-100, poly(L$\left.\mathrm{Glu}^{80} \cdot \mathrm{Tyr}^{20}\right)(44.5-45.7 \mathrm{kDa})$, and poly(L-lysine) (38 kDa) were purchased from Sigma. Thin layer $(0.1 \mathrm{~mm})$ cellulosecoated chromatographic plates and Hepes were obtained from Merck. Other chemicals used in this work were of analytical grade. The properties of the highly specific monoclonal antibody to calmodulin used in this study have been previously described (Sacks et al., 1991).

\section{Preparation of liver plasma membrane fractions}

Liver plasma membrane fractions from young adult male Sprague-Dawley albino rats $(200-250 \mathrm{~g})$ were prepared at $4^{\circ} \mathrm{C}$ as previously described (San José et al., 1993). In most preparations the homogenization in a glass/Teflon homogenizer was increased up to 20 strokes and the 15 s homogenization with a Polytron was omitted. To avoid proteolysis of the EGF receptor, $2 \mu \mathrm{M}$ leupeptin was added to the buffers. For the preparation of plasma membrane fractions depleted of the calcium-dependent bound calmodulin pool, $1 \mathrm{mM}$ EGTA was added to all buffers and sucrose gradient solutions. The membranes were finally resuspended in an EGTAfree buffer.

\section{Calmodulin-affinity chromatography}

The isolation of the EGF receptor by calmodulin-affinity chromatography was performed essentially as described earlier (San José et al., 1992). Briefly, membranes were solubilized in a medium containing $25 \mathrm{mM}$ sodium Hepes, $\mathrm{pH} 7.4,5 \%$ (mass/vol.) glycerol, $2 \mu \mathrm{M}$ leupeptin and $1 \%$ (mass/vol.) Triton X-100 for $10 \mathrm{~min}$ at $4^{\circ} \mathrm{C}$, and centrifuged at $130000 \mathrm{~g}$ for $1 \mathrm{~h} .100 \mu \mathrm{M} \mathrm{CaCl}_{2}$ was then added to the supernatant and this was loaded onto a calmodulin-agarose column (4-5 $\mathrm{ml}$ bed volume containing 5-6 mg linked calmodulin) equilibrated with $25 \mathrm{mM}$ sodium Hepes, $\mathrm{pH} 7.4$, 5\% (mass/vol.) glycerol, 1\% (mass/vol.) Triton X-1C0 and $100 \mu \mathrm{M} \mathrm{CaCl} 2\left(\mathrm{Ca}^{2+}\right.$ buffer $)$. After extensive washing with the $\mathrm{Ca}^{2+}$ buffer, bound proteins were eluted with the same buffer containing $1 \mathrm{mM}$ EGTA instead of $\mathrm{CaCl}_{2}$, and 0.75 $\mathrm{ml}$ fractions were collected. It is important to solubilize the membranes in the presence of leupeptin and in the absence of exogenous $\mathrm{Ca}^{2+}$ to prevent partial proteolysis of the EGF receptor by $\mathrm{Ca}^{2+}$-dependent proteases (Wang et al., 1989). Therefore, $\mathrm{CaCl}_{2}$ was added just before loading the column. The chromatographic procedure was carried out at $4^{\circ} \mathrm{C}$.

\section{Phosphorylation assays}

Standard phosphorylation assays, unless indicated otherwise, were carried out at $37^{\circ} \mathrm{C}$ for $5 \mathrm{~min}$ in a total volume of $100 \mu \mathrm{l}$ in a medium containing $15 \mathrm{mM}$ sodium Hepes, $\mathrm{pH} 7.4, \quad 6 \mathrm{mM} \quad \mathrm{MgCl}_{2}, \quad 10 \mu \mathrm{M} \quad\left[\gamma_{-}{ }^{32} \mathrm{P}\right] \mathrm{ATP} \quad(2-5 \mu \mathrm{Ci})$, $0.26 \mu \mathrm{M}$ poly(L-lysine) (when added), 3-6 $\mu \mathrm{M}$ histone (when added), $1 \mu \mathrm{M}$ calmodulin (when added), $1 \mu \mathrm{M}$ EGF (when added) and $50 \mu \mathrm{l}$ of the EGTA-eluted fraction from the calmodulin-agarose column. The assay system also contained $0.5 \mathrm{mM}$ EGTA, $2.5 \%$ (mass/vol.) glycerol, and $0.5 \%$ (mass/ vol.) Triton X-100, carried over from the EGTA-eluted fraction. In all experiments the EGTA-eluted fraction was incubated for $30 \mathrm{~min}$ on ice in the presence of EGF prior to phosphorylation. The reaction was initiated by adding radiolabeled ATP and stopped with ice-cold $10 \%$ (mass/vol.)

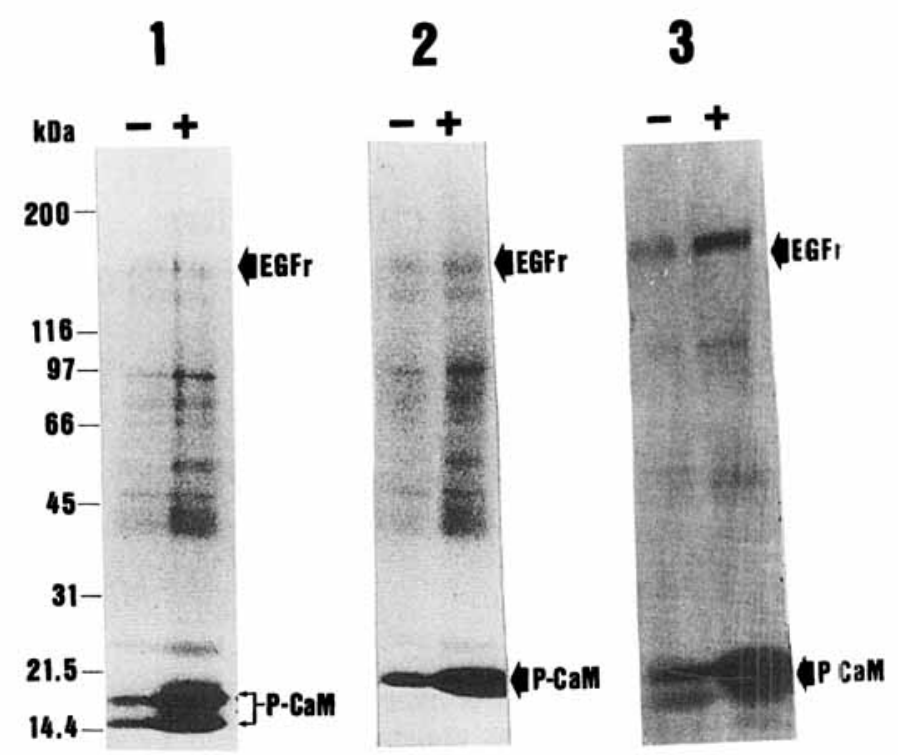

Fig. 1. Phosphorylation of calmodulin by the EGF receptor. (1 and 2) The EGF-receptor preparation $(50 \mu 1)$ was incubated at $37^{\circ} \mathrm{C}$ for $5 \mathrm{~min}$ in $100 \mu \mathrm{l}$ of a medium containing $15 \mathrm{mM}$ sodium Hepes, pH 7.4, $6 \mathrm{mM} \mathrm{MgCl}, 0.5 \mathrm{mM}$ EGTA, $0.5 \%$ (mass/vol.) Triton X$100,2.5 \%$ (mass/vol.) glycerol, $1.2 \mu \mathrm{M}$ calmodulin, $0.26 \mu \mathrm{M}$ poly(L-lysine) and $50 \mu \mathrm{M}\left[\gamma_{-}{ }^{32} \mathrm{P}\right] \mathrm{ATP}(2 \mu \mathrm{Ci})$, in the absence $(-)$ or presence $(+)$ of $1 \mu \mathrm{M}$ EGF. (3) The assays were performed as above, except that poly(L-lysine) was replaced by $3 \mu \mathrm{M}$ histone. In addition, $1 \mu \mathrm{M}$ calmodulin and $10 \mu \mathrm{M}\left[\gamma^{-32} \mathrm{P}\right]$ ATP $(1.6 \mu \mathrm{Ci})$ were used. The sample buffer for electrophoresis contained $10 \mathrm{mM} \mathrm{CaCl}_{2}$ (in 1) or $10 \mathrm{mM}$ EGTA (in 2 and 3). The arrows indicate the position of migration of the autophosphorylated EGF receptor (EGFr) and phosphocalmodulin (P-CaM) in the autoradiographs.

trichloroacetic acid (final concentration). The precipitated proteins were separated by centrifugation, the supernatant was discarded, and the pellet was processed by electrophoresis and autoradiography as described below.

\section{Phosphoamino acid analysis}

Phosphoamino acid analysis was carried out essentially as described by Hunter and Sefton (1980). The ${ }^{32}$ P-phosphorylated bands were cut from the dry gel, rehydrated in

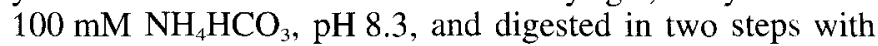
$150 \mu \mathrm{g}$ L-tosylamido-2-phenylchloromethyl ketone (Tos$\mathrm{PheCH}_{2} \mathrm{Cl}$ )-treated trypsin for $18 \mathrm{~h}$. The supernatant was lyophilized twice and treated with $6 \mathrm{M} \mathrm{HCl}$ at $110^{\circ} \mathrm{C}$ for $2 \mathrm{~h}$. The lyophilized samples were separated by two-dimensional electrophoresis in thin-layer $(0.1 \mathrm{~mm})$ chromatographic cellulose plates as follows. The first dimension was carried out in $2.2 \%$ (by vol.) formic acid and $8.7 \%$ (by vol.) acetic acid, $\mathrm{pH} \mathrm{1.9}$, and the second dimension was carried out in $0.5 \%$ (by vol.) pyridine and 5\% (by vol.) acetic acid, $\mathrm{pH} 3.5$. Phosphoserine, phosphothreonine and phosphotyrosine standards were stained with $0.1 \%$ (mass/vol.) ninhydrin in ethanol. The plates were dried and autoradiography was performed.

\section{Other analytical procedures}

Slab-gel electrophoresis was performed according to Laemmli (1970) at $12 \mathrm{~mA}$ overnight in linear gradient from $5 \%$ to $20 \%$ (mass $/ \mathrm{vol}$.) polyacrylamide gels in the presence of $0.1 \%$ (mass/vol.) SDS at $\mathrm{pH} 8.3$, with the addition of $10 \mathrm{mM} \mathrm{CaCl} \mathrm{Cl}_{2}$ or $10 \mathrm{mM}$ EGTA in the sample buffer. The 


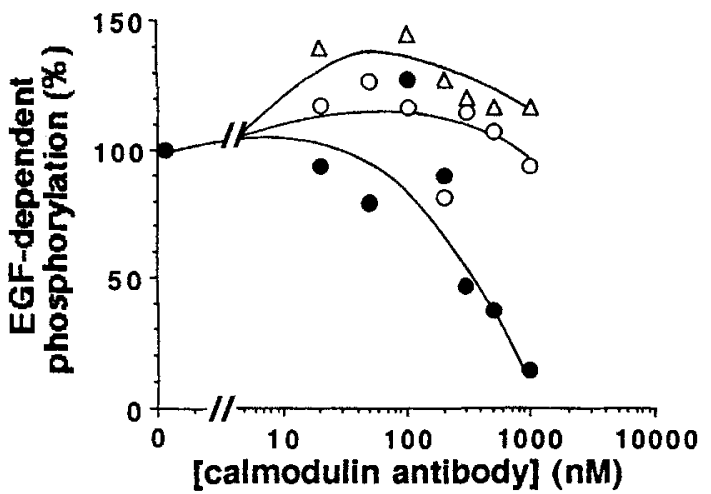

Fig. 2. A monoclonal antibody against calmodulin prevents its phosphorylation. Calmodulin $(0.1 \mu \mathrm{M})$, previously incubated for $90 \mathrm{~min}$ at $0^{\circ} \mathrm{C}$ with the indicated concentrations of the monoclonal antibody against calmodulin, was phosphorylated by the EGF-receptor preparation $(40 \mu \mathrm{l})$ in the absence and in the presence of $1 \mu \mathrm{M}$ EGF for $3 \mathrm{~min}$ at $37^{\circ} \mathrm{C}$ in $100 \mu \mathrm{l}$ of a medium containing $15 \mathrm{mM}$ sodium Hepes, $\mathrm{pH} 7.4,6 \mathrm{mM} \mathrm{MgCl}_{2}, 0.4 \%$ (mass/vol.) Triton X$100,2 \%$ (mass/vol.) glycerol, $0.4 \mathrm{mM}$ EGTA, $0.5 \mu \mathrm{M}$ histone, and $100 \mu \mathrm{M}\left[\gamma^{32} \mathrm{P}\right]$ ATP $(\mathbf{O})$. Control experiments were performed in a similar manner in the absence of calmodulin or histone, but in the presence of $0.1 \mathrm{mg} / \mathrm{ml}$ poly $\left(\mathrm{L}-\mathrm{Glu}^{80}, \mathrm{Tyr}^{20}\right)(O, \Delta)$. The plots represent the levels of EGF-dependent phosphorylation of calmodulin (O), and of poly(l-Glu $\left.{ }^{80}, \mathrm{Tyr}^{20}\right)(\mathrm{O})$, as well as the EGF-dependent autophosphorylation of the EGF receptor $(\triangle)$.

gels were stained with Coomassie Brilliant Blue R-250, dried under vacuum at $70^{\circ} \mathrm{C}$ on Whatman $3 \mathrm{MM} \mathrm{Chr}$ filter paper and exposed to blue-sensitive X-ray films at $-20^{\circ} \mathrm{C}$ for $2-$ 7 days. The intensity of the ${ }^{32} \mathrm{P}$-labeled calmodulin band (separated by electrophoresis in the presence of EGTA) was quantified by scanning the autoradiograph in a photodensitometer. The photodensitometric intensities of the ${ }^{32} \mathrm{P}$-labeled bands in the autoradiographs are directly proportional to the amount of ${ }^{32} \mathrm{P}$ in the bands, within the exposure time used. Protein concentrations were determined by the method of Lowry et al. (1951), after precipitating the proteins with $10 \%$ (mass/vol.) trichloroacetic acid, and using bovine serum albumin as a standard.

\section{RESULTS}

\section{Phosphorylation of calmodulin by the EGF receptor requires the presence of a basic polypeptide}

We isolated the EGF receptor from solubilized rat liver plasma membrane fractions by affinity chromatography on a calmodulin-agarose column as described earlier (San José et al., 1992). The EGTA-eluted fractions obtained from this column were used to phosphorylate calmodulin.

In the absence of a basic protein or polycation, calmodulin is not phosphorylated by the EGF receptor in the absence or presence of EGF (data not shown). Under these conditions, the major ${ }^{32} \mathrm{P}$-labeled protein observed in the autoradiograph migrates at $170 \mathrm{kDa}$ and its phosphorylation is stimulated by EGF. This band corresponds to the autophosphorylated EGF receptor (San José et al., 1992). Addition of poly(L-lysine) (Fig. 1) or histone (Fig. 1) results in the phosphorylation of calmodulin (Fig. 1, P-CaM). As can be observed (Fig. 1) by comparing samples incubated in the absence or presence of EGF, the ligand strongly stimulates the phosphorylation of calmodulin (3-7.5-fold). The presence of poly(L-lysine) also enhances the phosphorylation of other
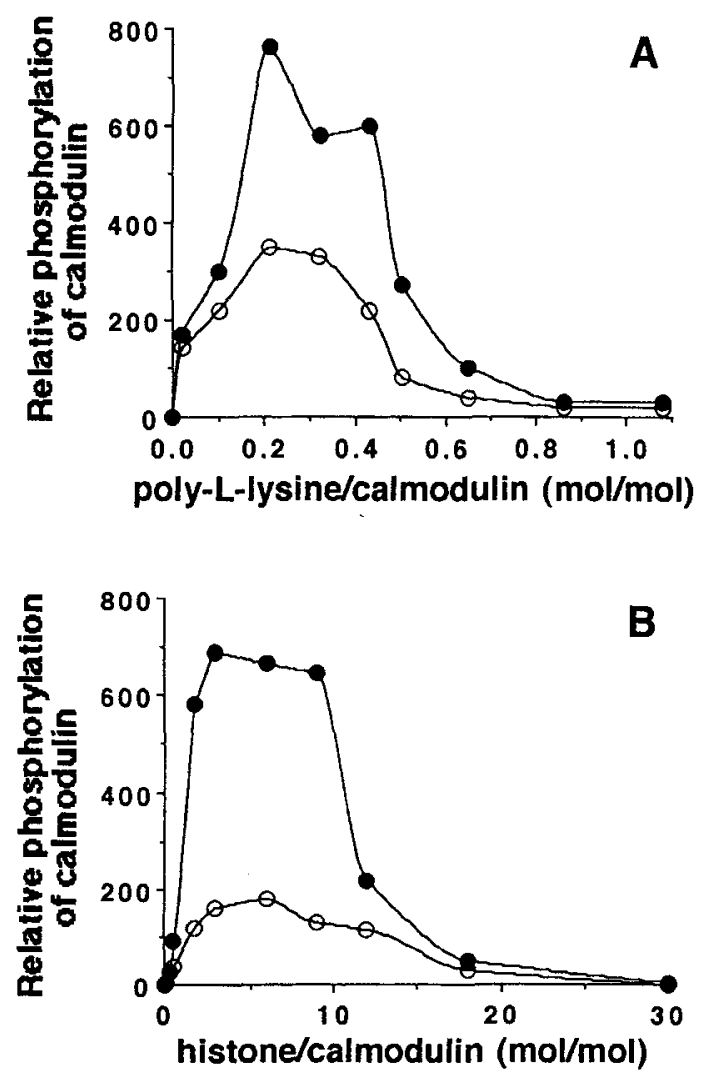

Fig. 3. Effect of the molar ratio of basic protein or polycation to calmodulin on the phosphorylation of calmodulin. (A) Calmodulin $(1.2 \mu \mathrm{M})$ was phosphorylated by the EGF-receptor preparation $(50 \mu \mathrm{l})$ at $37^{\circ} \mathrm{C}$ for $5 \mathrm{~min}$ in $100 \mu \mathrm{l}$ of a medium containing $15 \mathrm{mM}$ sodium Hepes, $\mathrm{pH} 7.4,6 \mathrm{mM} \mathrm{MgCl}, 0.5 \mathrm{mM}$ EGTA, $0.5 \%$ (mass/ vol.) Triton $\mathrm{X}-100,2.5 \%$ (mass/vol.) glycerol, $10 \mu \mathrm{M}\left[\gamma_{-}{ }^{32} \mathrm{P}\right] \mathrm{ATP}$ $(2 \mu \mathrm{Ci})$ and at different concentrations of poly(L-lysine), in the absence $(O)$ or presence $(O)$ of $1 \mu \mathrm{M}$ EGF. (B) The assays were performed as in (A) except that $1 \mu \mathrm{M}$ calmodulin was used and poly $(\mathrm{L}-$ lysine) was replaced by different concentrations of histone. The plots present the levels of phosphorylation of calmodulin determined densitometrically in the autoradiograph versus the poly(L-lysine)/calmodulin (A) or histone/calmodulin (B) molar ratios.

unidentified proteins, which are probably present in the EGFreceptor preparation. However, this problem is eliminated in part by using histone instead of poly(L-lysine). As anticipated, EGF also enhances autophosphorylation of the EGF receptor (Fig. 1, EGFr).

We also show in Fig. 1 that phosphocalmodulin exhibits the $\mathrm{Ca}^{2+}$-induced electrophoretic mobility shift, migrating as a double band at $16.5 \mathrm{kDa}$ (major component) in the presence of calcium and as a single band at $21 \mathrm{kDa}$ in the presence of EGTA. This change of mobility enables separation of phosphocalmodulin from phosphohistone in the autoradiograph. Both phosphocalmodulin (Fig. 1) and non-phosphorylated calmodulin (data not shown) migrate as two bands when electrophoresis is performed in the presence of calcium. To further ascertain that the observed $16.5-\mathrm{kDa} / 21-\mathrm{kDa}$ phosphorylated band was indeed phosphocalmodulin the effect of a highly specific monoclonal antibody against calmodulin (Sacks et al. 1991) was tested on its phosphorylation. As observed in Fig. 2, this antibody strongly inhibits the EGFdependent phosphorylation of calmodulin, without significantly affecting the phosphorylation of the substrate poly(L$\mathrm{Glu}^{80}, \mathrm{Tyr}^{20}$ ) or the autophosphorylation of the EGF receptor. 

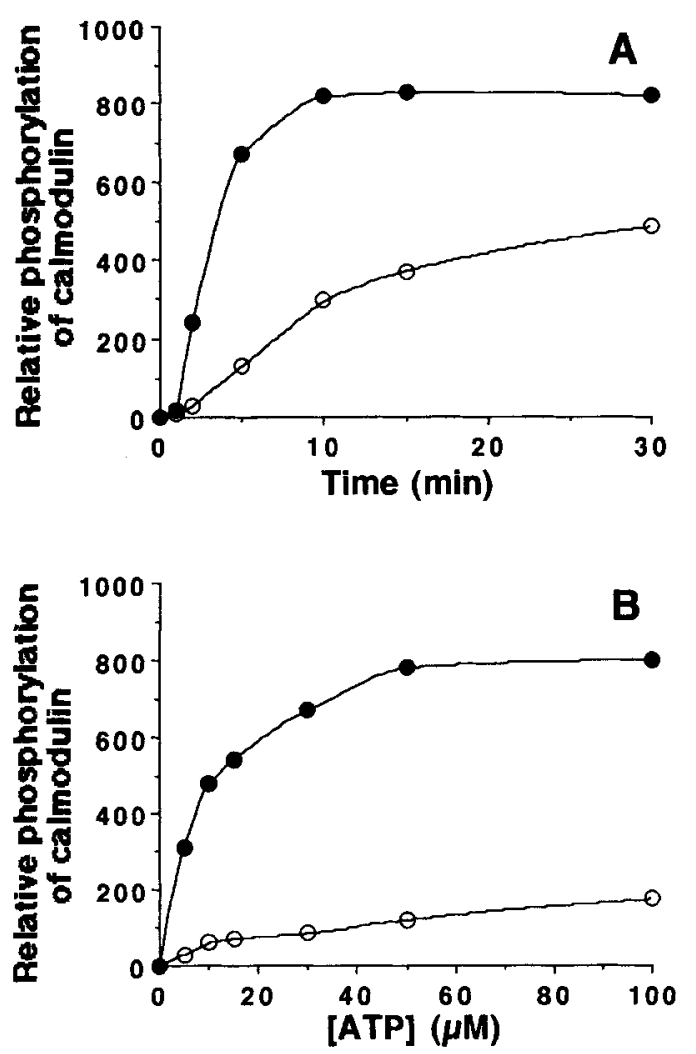

Fig. 4. Time-course of calmodulin phosphorylation (A), and effect of the concentration of ATP (B). (A) Calmodulin $(1 \mu \mathrm{M})$ was phosphorylated by the EGF-receptor preparation $(350 \mu \mathrm{l})$ at $37^{\circ} \mathrm{C}$ in $700 \mu$ of a medium containing $15 \mathrm{mM}$ sodium Hepes, pH 7.4,6 mM $\mathrm{MgCl}_{2}, 0.5 \mathrm{mM}$ EGTA, $0.5 \%$ (mass/vol.) Triton X-100, 2.5\% (mass/ vol.) glycerol, $6 \mu \mathrm{M}$ histone, and $10 \mu \mathrm{M}\left[\gamma^{-32} \mathrm{P}\right] \mathrm{ATP}(2 \mu \mathrm{Ci})$, in the absence $(O)$ or presence $(0)$ of $1 \mu \mathrm{M}$ EGF. At the indicated times, $100 \mu \mathrm{l}$ aliquots of the reaction mixture were removed and processed as described in Materials and Methods. The plots represent the level of phosphorylation of calmodulin determined densitometrically in the autoradiograph at different times. (B) Calmodulin $(1 \mu \mathrm{M})$ was phosphorylated by the EGF-receptor preparation $(40 \mu \mathrm{l})$ at $37^{\circ} \mathrm{C}$ for $5 \mathrm{~min}$ in $100 \mu \mathrm{l}$ of a medium containing $15 \mathrm{mM}$ sodium Hepes, $\mathrm{pH} 7.4,6 \mathrm{mM} \mathrm{MgCl}_{2}, 0.4 \mathrm{mM}$ EGTA, $0.4 \%$ (mass/vol.) Triton X$100,2 \%$ (mass/vol.) glycerol, $6 \mu \mathrm{M}$ histone, and the indicated concentrations of $\left[\gamma-{ }^{32} \mathrm{P}\right] \mathrm{ATP}$, in the absence $(\mathrm{O})$ or presence $(0)$ of $1 \mu \mathrm{M}$ EGF. The plots represent the levels of phosphorylation of calmodulin determined densitometrically in the autoradiograph versus the concentration of ATP.

We also demonstrate that the molar ratio of poly(L-lysine) or histone to calmodulin exhibits a narrow range for the optimal phosphorylation of calmodulin. Fig. 3 presents plots of the levels of phosphorylation of calmodulin at progressively higher poly(L-lysine)/calmodulin (Fig. 3A) or histone/calmodulin (Fig. 3B) molar ratios. In both cases it is observed that the phosphorylation of calmodulin increases to reach a maximum, and dramatically decreases as these molar ratios increase. Similar results were obtained in the absence and in the presence of EGF. We calculated from these plots an optimal poly(L-lysine)/calmodulin molar ratio of 0.2 , and an optimal histone/calmodulin molar ratio of 3-9 to attain maximum levels of calmodulin phosphorylation. The higher number of positive charges in poly(L-lysine) compared to histone is likely to account for the lower molar ratio when poly(L-lysine) is used.

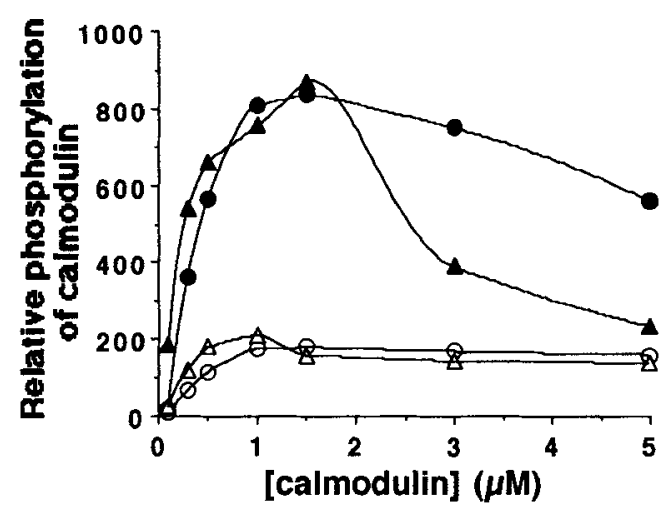

Fig. 5. Effect of the concentration of calmodulin on its phosphorylation. The indicated concentrations of calmodulin were phosphorylated by the EGF-receptor preparation $(50 \mu 1)$ at $37^{\circ} \mathrm{C}$ for $5 \mathrm{~min}$ in $100 \mu \mathrm{l}$ of a medium containing $15 \mathrm{mM}$ sodium Hepes, $\mathrm{pH} 7.4,6 \mathrm{mM} \mathrm{MgCl}, 0.5 \mathrm{mM}$ EGTA, $0.5 \%$ (mass/vol.) Triton X$100,2.5 \%$ (mass/vol.) glycerol and $50 \mu \mathrm{M}\left[\gamma^{-32} \mathrm{P}\right] \mathrm{ATP}(1.5 \mu \mathrm{Ci})$, in the absence $(\triangle, O)$ or presence $(\Delta, \boldsymbol{O})$ of $1 \mu \mathrm{M}$ EGF. The assays contained either a constant concentration $(3 \mu \mathrm{M})$ of histone in order to vary the histone/calmodulin molar ratio $(\triangle, \mathbf{A})$, or variable concentrations of histone to maintain a histone/calmodulin molar ratio of $3: 1(0,0)$. The plot presents the level of phosphorylation of calmodulin determined densitometrically in the autoradiograph versus the concentration of calmodulin.

\section{Kinetic parameters \\ for the phosphorylation of calmodulin}

Some kinetic parameters for the phosphorylation of calmodulin in the presence of histone have been determined. Fig. 4A presents time-courses of phosphorylation of calmodulin carried out in the absence or presence of EGF. An initial short lag phase occurs before the reaction attains its maximum rate, then remaining virtually constant for $5 \mathrm{~min}$ in the presence of EGF, and for $10 \mathrm{~min}$ in its absence. Thereafter, the reaction rate decreases until eventually the reaction comes to a halt. The maximum reaction rate in the presence of EGF is sixfold higher than in the absence of the ligand.

When the assays are performed at different concentrations of ATP (Fig. 4B), the phosphorylation of calmodulin follows a saturation curve close to Michaelis-Menten kinetics in the presence of EGF. We calculated from this plot an apparent association constant for ATP $\left[K_{0.5(\mathrm{ATP})}\right]$ of approximately $4-5 \mu \mathrm{M}$. The reaction also tends to saturation when the phosphorylation occurs in the absence of EGF. From this plot we determined that the phosphorylation of calmodulin was approximately eightfold higher in the presence than in the absence of EGF.

Phosphorylation assays were also performed at different concentrations of calmodulin in the absence or presence of EGF, as shown in Fig. 5. Previously we have seen in Fig. 3B, that the molar ratio of histone to calmodulin appears to be critical to obtain maximum levels of phosphorylation of calmodulin. Therefore, to study the calmodulin-concentration dependency of this phosphorylation process, these experiments were carried out in two different manners. In one case we maintained a constant histone/calmodulin molar ratio of $3: 1$ (Fig. 5). In the other case, the histone/calmodulin molar ratio was varied by maintaining a constant concentration of histone at $3 \mu \mathrm{M}$ and changing the concentration of calmodulin (Fig. 5). We calculated from these plots an apparent association constant for calmodulin $\left[K_{0.5(\mathrm{CaM})}^{\prime}\right]$ of approxi- 

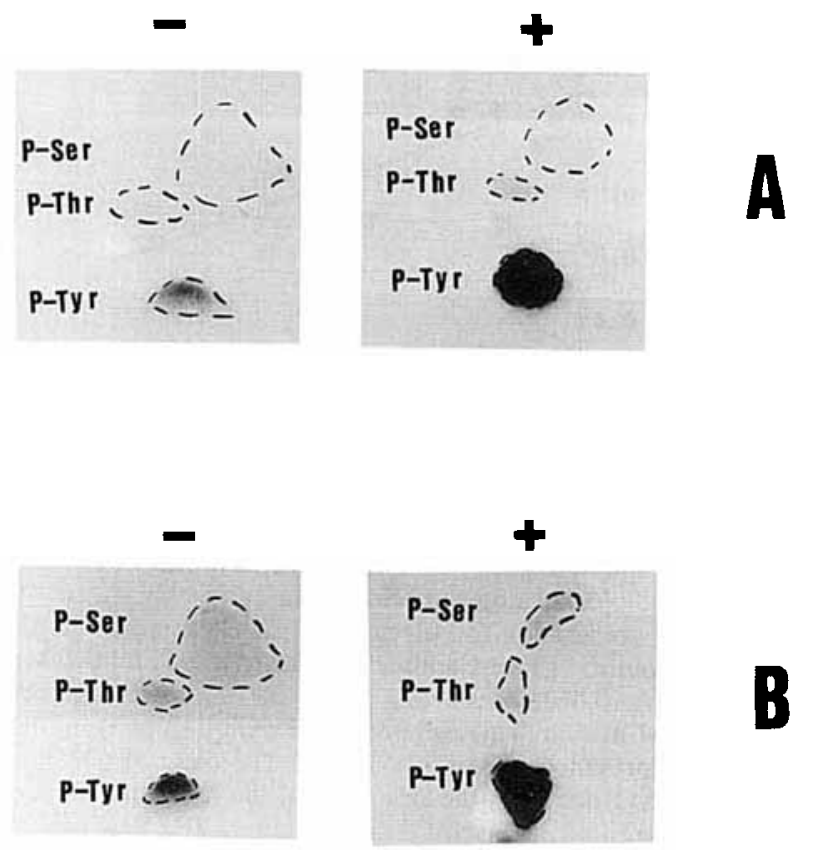

Fig. 6. Phosphoamino acid analysis of phosphocalmodulin. Calmodulin $(1 \mu \mathrm{M})$ was phosphorylated by the EGF-receptor preparation $(50 \mu \mathrm{l})$ at $37^{\circ} \mathrm{C}$ for $5 \mathrm{~min}$ in $100 \mu \mathrm{l}$ of a medium containing $15 \mathrm{mM}$ sodium Hepes, $\mathrm{pH} 7.4,6 \mathrm{mM} \mathrm{MgCl}_{2}, 0.5 \mathrm{mM}$ EGTA, $0.5 \%$ (mass/vol.) Triton X-100, 2.5\% (mass/vol.) glycerol and $50 \mu \mathrm{M}[\gamma$ $\left.{ }^{32} \mathrm{P}\right] \mathrm{ATP}(15 \mu \mathrm{Ci})$, in the absence $(-)$ or presence $(+)$ of $1 \mu \mathrm{M} \mathrm{EGF}$, and in the presence of $0.26 \mu \mathrm{M}$ poly(L-lysine) (A), or $6 \mu \mathrm{M}$ histone (B). The band of phosphocalmodulin was cut from the dry gel and processed for phosphoamino acid analysis as described in Materials and Methods. The position of migration of standard phosphoamino acids stained with ninhydrin are indicated in the autoradiographs by dashed lines.

mately $0.2-0.4 \mu \mathrm{M}$ both in the absence and presence of EGF.

An excess of calmodulin inhibits EGF-receptor-mediated calmodulin phosphorylation (Fig. 5). This inhibitory effect is most pronounced at high concentrations of calmodulin in experiments performed at fluctuating histone/calmodulin molar ratios, where free calmodulin is expected to accumulate. In contrast, when the histone/calmodulin molar ratio remains constant, the decrease in phosphorylation with increasing calmodulin concentrations was less evident. The observed inhibitory action of free calmodulin confirms our earlier results (San José et al., 1992).

\section{The EGF receptor phosphorylates calmodulin on Tyr99 with high stoichiometry}

Phosphoamino acid analysis of phosphocalmodulin was performed to determine whether calmodulin is phosphorylated on tyrosine residues.

Fig. 6 presents autoradiographs of the phosphoamino acids of calmodulin when the phosphorylation is performed in the absence or presence of EGF, either in the presence of poly(L-lysine) (Fig. 6A) or histone (Fig. 6B). We observe that under basal conditions (in the absence of EGF) phosphorylation of tyrosine occurs. Addition of EGF results in a significant increase of phosphotyrosine. Trace amounts of phosphoserine and phosphothreonine are also observed, particu-

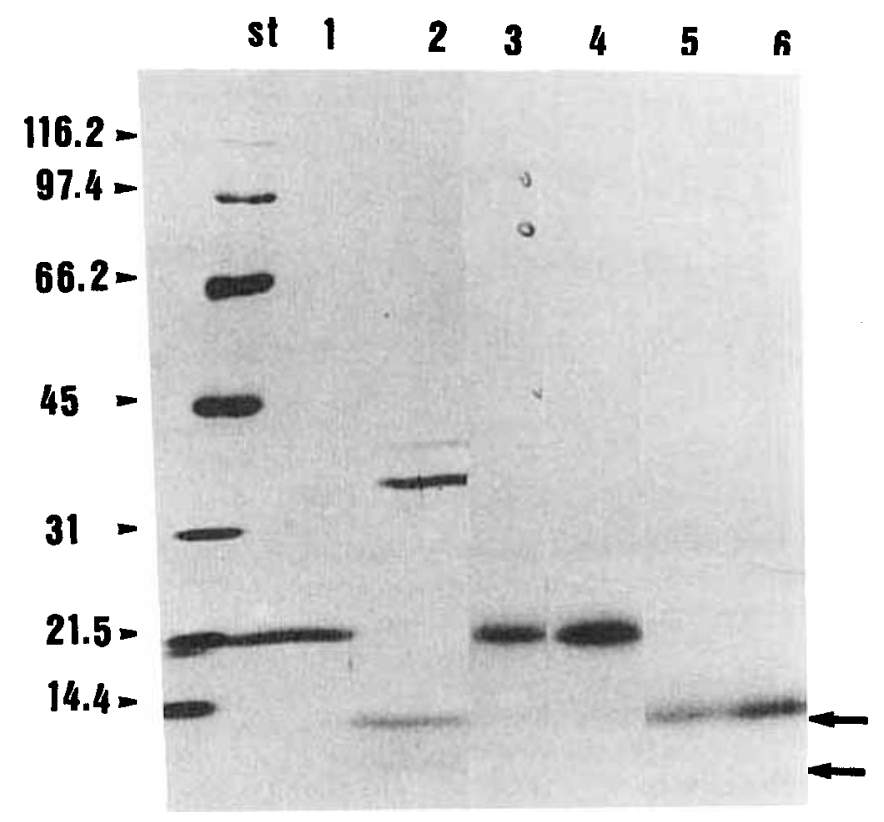

Fig. 7. Thrombin digestion of $\left[{ }^{32} \mathrm{P}\right]$ phosphocalmodulin produces a major labeled fragment containing phosphoTyr99. Calmodulin $(1 \mu \mathrm{M})$ was phosphorylated by the EGF-receptor preparation $(100 \mu \mathrm{l})$ at $37^{\circ} \mathrm{C}$ for $5 \mathrm{~min}$ in $200 \mu \mathrm{l}$ of a medium containing $15 \mathrm{mM}$ sodium Hepes, pH 7.4, $6 \mathrm{mM} \mathrm{MgCl}, 0.5 \mathrm{mM}$ EGTA, $0.5 \%$ (mass/ vol.) Triton X-100, 2.5\% (mass/vol.) glycerol, $3 \mu \mathrm{M}$ histone, and $50 \mu \mathrm{M}\left[\gamma_{-}{ }^{32} \mathrm{P}\right] \mathrm{ATP}(2 \mu \mathrm{Ci})$, in the absence (lanes 3 and 5$)$ or presence (lanes 4 and 6 ) of $1 \mu \mathrm{M}$ EGF. The reaction was stopped with icecold $10 \%$ (mass/vol.) trichloroacetic acid (final concentration), and the precipitated proteins were neutralized and resuspended in $1 \mathrm{ml}$ $20 \mathrm{mM} \mathrm{NH}_{4} \mathrm{HCO}_{3}$, pH 7.5, containing $100 \mu \mathrm{M} \mathrm{CaCl}$. The mixture was loaded onto a phenyl-Sepharose column equilibrated with the same buffer, and phosphocalmodulin was eluted from the column

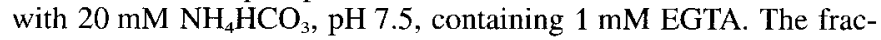
tion containing phosphocalmodulin was lyophilized and suspended in $100 \mu \mathrm{l} 25 \mathrm{mM}$ sodium Hepes, $\mathrm{pH} 7.4$. $10 \mathrm{U}$ thrombin in $10 \mu \mathrm{l}$ $50 \mathrm{mM}$ Tris $/ \mathrm{HCl}, \mathrm{pH} 8,1 \mathrm{mM}$ dithiothreitol and $5 \mathrm{mM}$ EGTA (lanes 5 and 6 ), or $10 \mu 1$ of the same buffer in the absence of thrombin (lanes 3 and 4) were then added. After $1 \mathrm{~min}$ at $37^{\circ} \mathrm{C}$, proteolysis was stopped by the addition of ice-cold $10 \%$ (mass/vol.) trichloroacetic acid (final concentration). The precipitated proteins were processed by electrophoresis (in the presence of $10 \mathrm{mM}$ EGTA in the sample buffer) and autoradiography as described in Materials and Methods (lanes 3-6). Control experiments containing $2 \mu \mathrm{g}$ calmodulin incubated as above in the absence (lane 1) or presence (lane 2) of thrombin stained with Coomassie Blue are presented. Molecular mass standard markers of the indicated $\mathrm{kDa}$ are given in lane st. Arrows point to the position of migration of the two major calmodulin thrombolytic fragments.

larly when histone is present in the assay. EGF does not increase the phosphorylation of serine or threonine residues. This indicates that the EGF receptor is not indirectly mediating the phosphorylation of calmodulin by activating serine/ threonine protein kinase(s), that could be present in the EGFreceptor preparations.

Mammalian calmodulin contains two tyrosine residues, Tyr99 and Tyr138 (Klee and Vanaman, 1982). Therefore, it was of interest to determine the specific site(s) of phosphorylation. To discriminate between the phosphorylation of Tyr99 and Tyr138 we took advantage of the selective proteolysis of phosphocalmodulin by thrombin. This protease cleaves calmodulin between residues 106 and 107 yielding a major fragment containing Tyr99 and a minor fragment containing Tyr138 (Wall et al., 1981). 


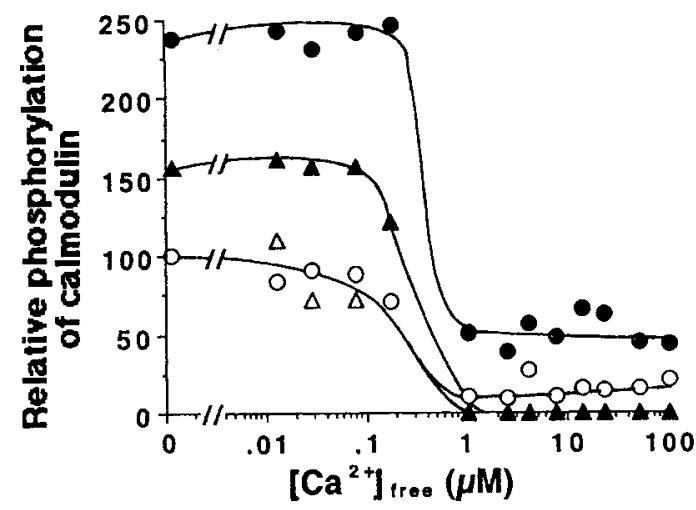

Fig. 8. $\mathrm{Ca}^{2+}$ at low concentrations prevents the phosphorylation of calmodulin. Calmodulin $(1 \mu \mathrm{M})$ was phosphorylated by the EGFreceptor preparation $(50 \mu 1)$ at $37^{\circ} \mathrm{C}$ for $3 \mathrm{~min}$ in $100 \mu \mathrm{l}$ of a medium containing $15 \mathrm{mM}$ sodium Hepes, $\mathrm{pH} 7.4,0.5 \%$ (mass/vol.) Triton $\mathrm{X}-100,2.5 \%$ (mass/vol.) glycerol, $0.5 \mathrm{mM}$ EGTA, $\mathrm{CaCl}_{2}$ to yield the indicated concentrations of free $\mathrm{Ca}^{2+}, 5 \mu \mathrm{M}$ histone $(\triangle, \boldsymbol{\Delta}), 0.2 \mu \mathrm{M}$ poly(L-lysine) $(\mathrm{O}, 0)$ and $10 \mu \mathrm{M}\left[\gamma-{ }^{32} \mathrm{P}\right] \mathrm{ATP}(2 \mu \mathrm{Ci})$, in the absence $(\triangle, \bigcirc)$ and in the presence $(\Delta, \bigcirc)$ of $1 \mu \mathrm{M}$ EGF. The plot presents the level of phosphorylation of calmodulin determined densitometrically in the autoradiograph at the indicated concentrations of free $\mathrm{Ca}^{2+}$.

In Fig. 7 it is shown that bovine brain calmodulin migrates at $21 \mathrm{kDa}$ on SDS/PAGE in which EGTA has been added to the electrophoresis sample buffer as observed after staining with Coomassie Blue. Treatment of non-phosphorylated calmodulin with thrombin results in the formation of a major fragment that migrates in the presence of EGTA as a polypeptide of apparent molecular mass of $14 \mathrm{kDa}$ and a minor fragment of lower molecular mass, hardly visible in the gel. Thrombin is observed in Fig. 7 lane 2 as a 35-kDa band. Fig. 7 also presents the autoradiograph of ${ }^{32} \mathrm{P}$-labeled calmodulin isolated by phenyl-Sepharose chromatography and its ${ }^{32} \mathrm{P}$-labeled fragment. Calmodulin was phosphorylated by the isolated EGF receptor in the absence or presence of EGF, using $\left[\gamma^{-32} \mathrm{P}\right]$ ATP. Lanes 3 and 4 (Fig. 7) present the autoradiograph of non-treated phosphocalmodulin, while lanes 5 and 6 (Fig. 7) present samples after treatment with thrombin. All the ${ }^{32} \mathrm{P}$ is incorporated into the higher-molecular-mass calmodulin fragment of $14 \mathrm{kDa}$, containing Tyr99, both in the absence and presence of EGF.

We have shown that phosphorylation of calmodulin by the EGF receptor tyrosine kinase occurs in the absence of $\mathrm{Ca}^{2+}$ (see above), and we have previously noticed that $\mathrm{Ca}^{2+}$ efficiently prevents this phosphorylation (San José et al., 1992). Nevertheless, the concentrations of $\mathrm{Ca}^{2+}$ previously used were well above a concentration range of physiological relevance. Therefore, we decided to analyze the effect of lower concentrations of this cation on the phosphorylation of calmodulin. Fig. 8 shows that $1 \mu \mathrm{M}$ free $\mathrm{Ca}^{2+}$ efficiently inhibits the phosphorylation of $1 \mu \mathrm{M}$ calmodulin. This inhibitory effect was observed in the absence or in the presence of EGF. Inhibition of calmodulin phophorylation occurs when both histone and poly(L-lysine) were used as cofactors, although the inhibitory effect was more pronunced in the presence of the former.

The stoichiometry of calmodulin phosphorylation at different concentrations of calmodulin was also examined. The plot presented in Fig. 9 shows the different experimental stoichiometric ratios determined in the absence or presence of EGF. In the absence of EGF, the stoichiometry was low, with values between $0.1 \mathrm{~mol}$ phosphate/mol calmodulin and

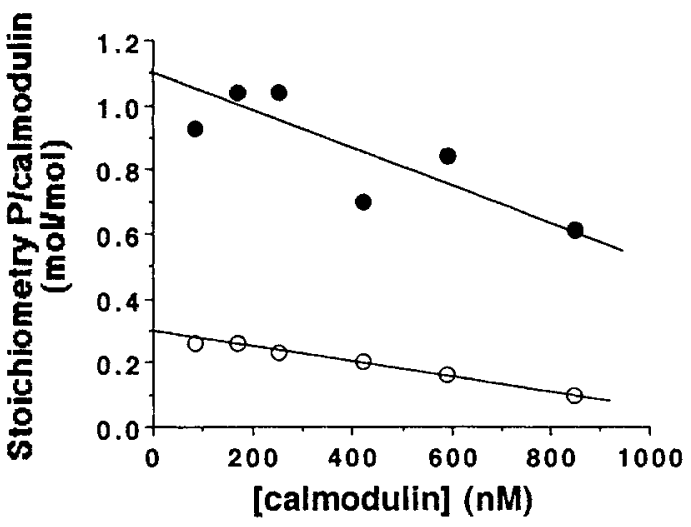

Fig. 9. Stoichiometric phosphate/calmodulin molar ratio. Calmodulin, at the indicated concentrations, was phosphorylated by the EGF-receptor preparation $(50 \mu 1)$ at $37^{\circ} \mathrm{C}$ for $30 \mathrm{~min}$ in $100 \mu$ of a medium containing $15 \mathrm{mM}$ sodium Hepes, $\mathrm{pH} 7.4,6 \mathrm{mM} \mathrm{MgCl}_{2}$, $0.5 \mathrm{mM}$ EGTA, $0.5 \%$ (mass/vol.) Triton X-100, 2.5\% (mass/vol.) glycerol, $3 \mu \mathrm{M}$ histone, and $100 \mu \mathrm{M}\left[\gamma^{3}{ }^{32} \mathrm{P}\right] \mathrm{ATP}(13 \mu \mathrm{Ci})$, in the absence $(O)$ or presence $(O)$ of $1 \mu \mathrm{M}$ EGF. The band of phosphocalmodulin was cut out from the dry gel and the level of ${ }^{32} \mathrm{P}$ incorporated was quantified in a scintillation counter. The amounts of ${ }^{32} \mathrm{P}$ incorporated $/ \mathrm{mol}$ calmodulin were calculated from an appropriate calibration obtained with different solutions of $\left[\gamma-{ }^{32} \mathrm{P}\right]$ ATP of known molarities.

$0.26 \mathrm{~mol}$ phosphate/mol calmodulin at concentrations of calmodulin of $850 \mathrm{nM}$ and $85 \mathrm{nM}$, respectively. Addition of EGF significantly increases the stoichiometry to $0.61 \mathrm{~mol} /$ $\mathrm{mol}$ and $1.04 \mathrm{~mol} / \mathrm{mol}$ at high and low concentrations of calmodulin, respectively. To determine the maximum mechanistic stoichiometry we extrapolated the straight line formed by the values of experimental stoichiometries using a linear regression to a point where the concentration of calmodulin tends to zero. Under these conditions, a theoretical stoichiometry of 0.3 was determined in the absence of EGF, and of 1.1 in its presence.

\section{DISCUSSION}

The EGF-receptor preparation used for the phosphorylation of calmodulin in this work was isolated by calmodulinaffinity chromatography (San José et al., 1992). It is known that the insulin receptor can also be isolated by this procedure (Graves et al., 1985), and we have observed that our preparations contain the insulin receptor (Benguría et al., 1993). However, autophosphorylation of the $\beta$ subunit of the insulin receptor was undetectable in the absence of insulin, and was observed only in the presence of $50 \mathrm{nM}$ insulin (Benguría et al., 1993). Furthermore, no insulin was present in our assays. Our results demonstrate that EGF markedly enhances the phosphorylation of both calmodulin and the EGF receptor. Additionally, the kinetic parameters of calmodulin phosphorylation, and the requirements for a basic protein or polycation were identical in the absence or presence of EGF. The only difference observed was in the rate of phosphorylation. Furthermore, both the EGF-receptor autophosphorylation and the kinase activity toward calmodulin, are equally enriched in the isolated EGF-receptor preparation by a similar factor (14-fold and 20-fold, respectively) when compared to the plasma membranes (data not shown). Therefore, it is extremely unlikely that the insulin receptor or other tyrosine kinase was responsible for significant phosphoryla- 
tion of calmodulin under the experimental conditions employed in this work.

It has been reported that poly(L-lysine) activates the EGF-receptor tyrosine kinase (Hubler et al., 1992). Therefore, poly(L-lysine) is expected to enhance the phosphorylation of calmodulin by this mechanism. This is supported by ${ }^{1} \mathrm{H}-\mathrm{NMR}$ and sedimentation equilibrium centrifugation studies showing that poly(L-lysine) associates with calmodulin in aqueous solution (Hardy et al., 1994).

We have demonstrated here that the EGF receptor phosphorylates calmodulin on Tyr99. Nevertheless, the poor resolution of the low-molecular-mass thrombolytic fragment of calmodulin in the gels prevents us from excluding the possibility that Tyr138 is not also phosphorylated to some extent. Tyr99 is also phosphorylated in calmodulin by the insulin receptor (Laurino et al., 1988). Additionaly, Tyr99, and to a lesser extent Tyr138, are both phosphorylated by the spleen tyrosine kinase type III (Meggio et al., 1987). There appears to be a striking difference in electrophoretic mobility between the species of phosphocalmodulin yielded upon phosphorylation with the insulin receptor and the EGF receptor. Non-phosphorylated calmodulin exhibits an altered migration on SDS/PAGE in the presence of calcium compared to its mobility in the absence of calcium (Burgess et al., 1980). A similar shift is observed with calmodulin phosphorylated by the EGF-receptor tyrosine kinase (San José et al., 1992; this work). In contrast, it has been reported that the electrophoretic migration of calmodulin phosphorylated by the insulin-receptor tyrosine kinase is not changed (Laurino et al., 1988), or only partially changed (Saville and Houslay, 1994) in the presence versus the absence of calcium. The reason(s) for these discrepancies are not clear but methodological differences might account for the disparities.

The concentration of cytoplasmic free $\mathrm{Ca}^{2+}$ is $10^{-8}-10^{-7}$ $\mathrm{M}$ in quiescent non-stimulated cells (Carafoli, 1987), and an early event occurring in cells activated by EGF and several other growth factors is a transient rise in the concentration of cytoplasmic free calcium reaching values of $10^{-6}-10^{-5}$ M (Rozengurt, 1986; Moolenaar et al., 1986; Pandiella et al., 1988). Calcium mobilization has been shown to be mediated by two concurrent mechanisms, although the relative importance of these two systems varies among cell types: the EGF-receptor tyrosine kinase activates phospholipase $\mathrm{C} \gamma$ which hydrolyzes phosphatidylinositol lipids, resulting in the release of inositol trisphosphate (Nishibe et al., 1990) that in turn activates intracellular $\mathrm{Ca}^{2+}$-channels most probably located in the endoplasmic reticulum (Berridge, 1993); and the sequential activation of extracellular voltage-insensitive and voltage-sensitive $\mathrm{Ca}^{2+}$ channels in the plasma membrane by leukotriene $\mathrm{C}_{4}$, formed by a phospholipase $\mathrm{A}_{2} / 5$-lipoxygenase pathway. This pathway is thought to be activated by phosphorylation of phospholipase $\mathrm{A}_{2}$ by the EGF-receptor tyrosine kinase (Peppelenbosch et al., 1992). We have demonstrated that phosphorylation of calmodulin by the EGF receptor is very sensitive to low concentrations of $\mathrm{Ca}^{2+}$. Free cytosolic $\mathrm{Ca}^{2+}$ undergoes oscillations (Berridge, 1990) which should modulate the extent of calmodulin phosphorylation. Therefore, it is reasonable to hypothesize that the levels of phosphorylation of calmodulin may exhibit analogous fluctuations in vivo.

Phosphorylation of calmodulin in vitro by the EGF-receptor tyrosine kinase only takes place in the presence of a basic protein or polycation. This has been previously observed when calmodulin is phosphorylated in vitro by the insulin-receptor tyrosine kinase (Graves et al., 1986; Sacks and McDonald, 1988; Sacks et al., 1989a; Laurino et al., 1988), by casein kinase-2 (Meggio et al., 1992; Sacks and McDonald, 1992), and by soluble spleen tyrosine kinase type III (Meggio et al., 1987). Since insulin enhances calmodulin phosphorylation in intact cells without the addition of a cationic protein or polypeptide (Sacks et al., 1992b), an endogenous basic protein may be implicated in the phosphorylation of calmodulin in vivo. The nature of this endogenous cofactor is of considerable interest as its identification could aid in the understanding of this phosphorylation process. The highly basic C-terminal region of the protein product of the c-Ki-ras protoncogene has been implicated in the phosphorylation of calmodulin by the insulin receptor (Sacks et al., 1989b; Fujita-Yamaguchi et al., 1989). This observation could also be of great relevance to the mechanism of calmodulin phosphorylation by the EGF-receptor tyrosine kinase. The Ras protein superfamily is central to the mechanism of cell proliferation and differentiation (Haubruck and McCormick, 1991), and the putative implication of the c-Ki-ras protein product in the control of the activity of the EGF receptor via calmodulin, could underscore a possible new mechanism for the control of mitosis by this protoncogene.

Since calmodulin is involved in the control of a great number of cellular processes (Means and Dedman, 1980; Klee et al., 1980; Klee and Vanaman, 1982; Manalan and Klee, 1984; Veigl et al., 1984; Strynadka and James, 1989; Bachs et al., 1992), we can anticipate that EGF-receptorTyr99-phosphorylated calmodulin may have profound effects on the different calmodulin-dependent pathways.

We are indebted to Dr. José Martín-Nieto for critically reading the manuscript. This work was supported in part by Research Grants to A. V. from the Comisión Interministerial de Ciencia y Tecnología (SAF392/93), and from the Secretaría de Educación de la Comunidad de Madrid (366/92). A. B. is the recipient of a predoctoral fellowship from the Departamento de Educación, Universidades e Investigación del Gobierno Vasco, O. H.-P. is the recipient of a predoctoral fellowships from the Cabildo Insular de Gran Canaria, Fundación Universitaria de Las Palmas, and from the Fundación Cientifica de la Asociación Española Contra el Cáncer, and M. T. M.-P. is the recepient of an undergraduate traineeship from the Consejo Superior de Investigaciones Científicas. Work at D. B. S. lab was supported by Research Grant DK43682 from the National Institutes of Health, USA.

\section{REFERENCES}

Bachs, O., Agell, N. \& Carafoli, E. (1992) Calcium and calmodulin function in the cell nucleus, Biochim. Biophys. Acta 1113, 259270.

Benguría, A., San José, E., Soriano, M., Elexpuru, A. \& Villalobo, A. (1993) Implicación de la calmodulina en la regulación del receptor del factor de crecimiento epidérmico, in Bases Moleculares del Cáncer, Aplicaciones Clínicas y Desarrollo Tecnológico. (Lacal, J. C. \& Barbacid, M., eds) pp. 35-54, Farmaindustria Serie Científica, Madrid.

Berridge, M. J. (1990) Calcium oscillations, J. Biol. Chem. 265, 9583-9586.

Berridge, M. J. (1993) Inositol trisphosphate and calcium signalling, Nature 361, 315-325.

Burgess, W. H., Jemiolo, D. K. \& Kretsinger, R. H. (1980) Interaction of calcium and calmodulin in the presence of sodium dodecyl sulfate, Biochim. Biophys. Acta 623, 257-270.

Carafoli, E. (1987) Intracellular calcium homeostasis, Annu. Rev. Biochem. 56, 395-433.

Colca, J. R., DeWald, D. B., Pearson, J. D., Palazuk, B. J., Laurino, J. P. \& McDonald, J. M. (1987) Insulin stimulates the phosphorylation of calmodulin in intact adipocytes, J. Biol. Chem. 262, $11399-11402$. 
Fujita-Yamaguchi, Y., Kathuria, S., Xu, Q.-Y., McDonald, J. M., Nakano, H. \& Kamata, T. (1989) In vitro tyrosine phosphorylation studies on RAS proteins and calmodulin suggest that polylysine-like basic peptides or domains may be involved in interaction between insulin receptor kinase and its substrate, Proc. Natl Acad. Sci. USA 86, 7306-7310.

Fukami, Y., Nakamura, T., Nakayama, A. \& Kanehisa, T. (1985) Phosphorylation of tyrosine residues of calmodulin in Rous sarcoma virus-transformed cells, Proc. Natl Acad. Sci. USA 83, 4190-4193.

Graves, C. B., Goewert, R. B. \& McDonald, J. M. (1985) The insulin receptor contains a calmodulin-binding domain, Science 230, $827-829$.

Graves, C. B., Gale, R. D., Laurino, J. P. \& McDonald, J. M. (1986) The insulin receptor and calmodulin. Calmodulin enhances insulin mediated receptor kinase activity and insulin stimulates phosphorylation of calmodulin, J. Biol. Chem. 261, 10429-10438.

Hardy, R. W., McDonald, J. M., Remsen, E. E., d'Avignon, D. A. \& Sacks, D. Б. (1994) The interaction of calmodulin and polylysine as studied by ${ }^{1} \mathrm{H}$ NMR spectroscopy and sedimentation equilibrium centrifugation, Biochem. Biophys. Res. Commun. 198, $309-317$.

Häring, H. U., White, M. F., Kahn, C. R., Ahmad, Z., DePaoliRoach, A. A. \& Roach, P. J. (1985) Interaction of the insulin receptor kinase with serine/threonine kinases in vitro, J. Cell. Biochem. 28, 171-182.

Haubruck, H. \& McCormick, F. (1991) Ras p21: effects and regulation, Biochim. Biophys. Acta 1072, 215-229.

Hubler, L., Leventhal, P. S. \& Bertics, P. J. (1992) Alteration of the kinetic properties of the epidermal growth factor receptor tyrosine kinase by basic proteins, Biochem. J. 281, 107-114.

Hunter, T. \& Sefton, B. M. (1980) Transforming gene product of Rous sarcoma virus phosphorylate tyrosine, Proc. Natl Acad. Sci. USA 77, 1311-1315.

Klee, C. B. \& Vanaman, T. C. (1982) Calmodulin, Adv. Protein Chem. 35, 213-321.

Klee, C. B., Crouch, T. H. \& Richman, P. G. (1980) Calmodulin, Annu. Rev. Biochem. 49, 489-515.

Kubo, M. \& Strott, C. A. (1988) Phosphorylation of calmodulin on threonine residue(s) by cytosol prepared from the adrenal cortex, Biochem. Biophys. Res. Commun. 156, 1333-1339.

Laemmli, U. K. (1970) Cleavage of structural proteins during the assembly of the head of bacteriophage T4, Nature 227, 680--685.

Laurino, J. P., Colca, J. R., Pearson, J. D., DeWald, D. B. \& McDonald, J. M. (1988) The in vitro phosphorylation of calmodulin by the insulin-receptor tyrosine kinase, Arch. Biochem. Biophys. $265,8-12$.

Lin, P. H., Selinfreund, R. \& Wharton, W. (1986) Epidermal growth factor (EGF) sensitive phosphorylation of calmodulin (CAM) in A431 cell membrane, Fed. Proc. 45, 1693.

Lowry, O. H., Rosebrough, N. J., Farr, A. L. \& Randall, R. J. (1951) Protein measurement with the Folin phenol reagent, J. Biol. Chem. 193, 265-275.

Manalan, A. S. \& Klee, C. B. (1984) Calmodulin, Adv. Cyclic Nucleotide Protein Phosphorylation Res. 18, 227-277.

Means, A. R. \& Dedman, J. R.(1980) Calmodulin an intracellular calcium receptor, Nature 285, 73-77.

Meggio, F., Brunati, A. M. \& Pinna, L. A. (1987) Polycation-dependent, $\mathrm{Ca}^{2+}$-antagonized phosphorylation of calmodulin by casein kinase-2 and a spleen tyrosine protein kinase, FEBS Lett. 215, $241-246$.

Meggio, F., Boldyreff, B., Marin, O., Marchiori, F., Perich, J. W., Issinger, O. G. \& Pinna, L. A. (1992) The effect of polylysine on casein-kinase- 2 activity is influenced by both the structure of the protein/peptide substrates and the subunit composition of the enzyme, Eur. J. Biochem. 205, 939-945.

Moolenaar, W. H., Aerts, R. J., Tertoolen, L. G. J. \& De Laat, S. W. (1986) The epidermal growth factor-induced calcium signal in A431 cells, J. Biol. Chem. 261, 279-284.

Nakajo, S., Hayashi, K., Daimatsu, T., Tanaka, M., Nakaya, K. \& Nakamura, Y. (1986) Phosphorylation of rat brain calmodulin in vivo and in vitro, Biochem. Int. 13, 687-693.

Nakajo, S., Masuda, Y., Nakaya, K. \& Nakamura, Y. (1988) Determination of the phosphorylation sites of calmodulin catalyzed by casein kinase 2, J. Biochem. (Tokyo) 104, 946-951.
Nishibe, S., Wahl, M. I., Hernández-Sotomayor, S. M. T., Tonks, M. K., Rhee, S. G. \& Carpenter, G. (1990) Increase of the catalytic activity of phospholipase $\mathrm{C}-\boldsymbol{\gamma} 1$ by tyrosine phosphorylation. $\mathrm{Sci}$ ence 250, 1253-1256.

Pandiella, A., Beguinot, L., Velu, T. J. \& Meldolesi, J. (1988) Transmembrane signalling at epidermal growth factor receptors overexpressed in NIH 3T3 cells. Phosphoinositide hydrolysis, cytosolic $\mathrm{Ca}^{2+}$ increase and alkalinization correlate with epidermalgrowth-factor-induced cell proliferation, Biochem. J. 254, 223228.

Peppelenbosch, M. P., Tertoolen, L. G. J., Den Hertog, J. \& De Laat, S. W. (1992) Epidermal growth factor activates calcium channels by phospholipase $\mathrm{A}_{2} / 5$-lipoxygenase-mediated leukotriene $\mathrm{C}_{4}$ production, Cell 69, 295-303.

Plancke, Y. D. \& Lazarides, E. (1983) Evidence for a phosphorylated form of calmodulin in chicken brain and muscle, Mol. Cell. Biol. 3, $1412-1420$.

Rozengurt, E. (1986) Early signals in the mitogenic response, $S_{c i}$ ence $234,161-166$.

Sacks, D. B. \& McDonald, J. M. (1988) Insulin-stimulated phosphorylation of calmodulin by rat liver insulin receptor preparations, J. Biol. Chem. 263, 2377-2383.

Sacks, D. B. \& McDonald, J. M. (1992) Effects of cationic polypeptides on the activity, substrate interaction, and autophosphorylation of casein kinase II: A study with calmodulin, Arch. Biochem. Biophys. 299, 275-280.

Sacks, D. B., Fujita-Yamaguchi, Y., Gale, R. D. \& McDonald, J. M. (1989a) Tyrosine-specific phosphorylation of calmodulin by the insulin receptor kinase purified from human placenta, Biochem. J. 263, 803-812.

Sacks, D. B., Glenn, K. C. \& McDonald, J. M. (1989b) The carboxyl terminal segment of the c-Ki-ras 2 gene product mediates insulin-stimulated phosphorylation of calmodulin and stimulates insulin-independent autophosphorylation of the insulin receptor, Biochem. Biophys. Res. Commun. 161, 399-405.

Sacks, D. B., Porter, S. H., Ladenson, J. H. \& McDonald, J. M. (1991) Monoclonal antibody to calmodulin. Development, characterization and comparison with polyclonal anti-calmodulin antibodies, Anal. Biochem. 194, 369-377.

Sacks, D. B., Davis, H. W., Williams, J. P., Sheehan, E. L., García, J. G. N. \& McDonald, J. M. (1992a) Phosphorylation by casein kinase II alters the biological activity of calmodulin, Biochem. J. 283, 21-24.

Sacks, D. B., Davis, H. W., Crimmins, D. L. \& McDonald. J. M. (1992b) Insulin-stimulated phosphorylation of calmodulin, Biochem. J. 286, 211-216.

San José, E., Benguría, A., Geller, P. \& Villalobo, A. (1992) Calmodulin inhibits the epidermal growth factor receptor tyrosine kinase, J. Biol. Chem. 267, 15237-15245.

San José, E., Benguría, A., Gabius, H.-J. \& Villalobo, A. 11993) Effects of lectins on adenylylation and phosphorylation of plasma membrane proteins, in Lectins and Glycobiology (Gabius, H.-J. \& Gabius, S., eds) pp. 329-355 Springer-Verlag, Heidelberg/New York.

Saville, M. K. \& Houslay, M. D. (1994) Phosphorylation of calmodulin on $\mathrm{Tyr}^{99}$ selectively attenues the action of calmodulin antagonists on type-I cyclic nucleotide phosphodiesterase activity, Biochem. J. 299, 863-868.

Strynadka, N. C. J. \& James, M. N. G. (1989) Crystal structures of the helix-loop-helix calcium-binding proteins, Annu. Rev. Biochem. 58, 951-998.

Veigl, M. L., Vanaman, T. C. \& Sedwick, W. D. (1984) Calcium and calmodulin in cell growth and transformation, Biochim. Biophys. Acta 738, 21-48.

Wall, C. M., Grand, R. J. A. \& Perry, S. V. (1981) Biological activities of the peptides obtained by digestion of troponin $\mathrm{C}$ and calmodulin with thrombin, Biochem. J. 195, 307-316.

Wang, K. K. W., Villalobo, A. \& Roufogalis, B. D. (1989) Calmodulin-binding proteins as calpain substrates, Biochem. J. 262, 693-706. 